\title{
Peranan Media Sosial Instagram, Harga Dan Kualitas Produk Terhadap Keputusan Pembelian Pada Toko Online Masker.Solopunya
}

\author{
Lyna ; Hilda Ditiolebiet. \\ Fakultas Ekonomi Universitas Kristen Surakarta \\ Jl. RW. Monginsidi No. 36-38 \\ lynaraharjo@yahoo.com
}

\begin{abstract}
This study aims to determine the role of Social Media Instagram, Price and Product Quality on Purchasing Decision. The population in this study were all active social media users. The sample used were 85 people with the conditions: at least have one active social media account and have visited and or purchased at the online shop "Masker.Solopunya". The sampling methods used were the nonprobability sampling methods with accidental sampling technique. The result showed that Social Media Instagram had a significant effect on Purchasing Decision, Price had a significant effect on Purchasing Decision, Product Quality had a significant effect on Purchasing Decision, and Social Media Instagram, Price and Product Quality simultaneously had a significant effect on Purchasing Decision.
\end{abstract}

Keywords- Price; Product Quality; Purchasing Decision; Social Media Instagram.

\begin{abstract}
Abstrak- Penelitian ini bertujuan untuk mengetahui Peran Media Sosial Instagram, Harga dan Kualitas Produk terhadap Keputusan Pembelian. Populasi dalam penelitian ini adalah seluruh pengguna media sosial aktif. Sampel yang digunakan sebanyak 85 orang dengan ketentuan: minimal memiliki satu akun media sosial aktif dan pernah berkunjung dan atau membeli di toko online Masker.Solopunya. Metode pengambilan sampel yang digunakan adalah metode non-probability sampling dengan teknik accidental sampling. Hasil penelitian menunjukkan bahwa Media Sosial Instagram berpengaruh signifikan terhadap Keputusan Pembelian, Harga berpengaruh signifikan terhadap Keputusan Pembelian, Kualitas Produk berpengaruh signifikan terhadap Keputusan Pembelian, dan Media Sosial Instagram, Harga dan Kualitas Produk berpengaruh signifikan secara simultan terhadap Pembelian Keputusan.
\end{abstract}

Kata Kunci- Harga; Kualitas Produk; Keputusan membeli; Media Sosial Instagram.

\section{PENDAHULUAN}

Adapun kondisi persaingan di pasar online sangat dinamis, membuat para pelaku usaha saling berlomba untuk menonjolkan keunggulan produk masing-masing[1], [2]. Pelaku usaha yang kreatif, tanggap kebutuhan pasar, serta memiliki kualitas keunggulan produk akan menarik perhatian calon pembeli. Pemasaran produk online yang semarak juga membuat konsumen menjadi memiliki banyak pilihan atau referensi dalam menentukan produk yang akan mereka pilih untuk dibeli dan digunakan. Persaingan yang ketat di pasar online bagi para pelaku usaha merupakan tantangan untuk selalu melakukan inovasi untuk mempertahankan loyalitas konsumen serta memenuhi kebutuhan konsumen. Selanjutnya, bagaimana membuat laman yang menarik dan mempengaruhi konsumen untuk percaya pada apa yang ditawarkan merupakan tantangan bagi para pelaku usaha[3].

Faktor-faktor yang mempengaruhi keputusan pembelian konsumen adalah harga, kualitas produk dan pemasaran yang efektif. Harga suatu barang atau jasa merupakan penentu bagi permintaan pasar dan merupakan salah satu elemen penting bagi usaha dalam melakukan strategi pemasaran[4], [5]. Harga harus sesuai dengan persepsi konsumen tentang produk yang akan di tawarkan. Penetapan harga yang berorientasi efektif mencakup memahami berapa besar nilai yang ditempatkan konsumen atas manfaat yang mereka terima dari produk tersebut dan penetapan harga yang sesuai dengan nilai. Harga yang sebanding dengan kualitas produk akan lebih memberikan konsumen loyal terhadap produk yang dijual. Harga yang efektif dan kualitas produk yang bagus bila didukung dengan strategi pemasaran yang efektif dan up to date, misalnya melalui jejaring media sosial membuat konsumen memiliki referensi yang cukup untuk mengambil keputusan dalam membeli produk[6].

\section{Sosial Media}

\section{KAJIAN PUSTAKA}

Media sosial adalah mengenai menjadi manusia biasa. Manusia biasa yang saling membagi ide, bekerjasama dan berkolaborasi untuk menciptakan kreasi, berfikir, berdebat, menemukan orang yang bisa 
menjadi teman baik, menemukan pasangan dan membangun sebuah komunitas. Intinya, menggunakan media sosial menjadikan kita sebagai diri sendiri. Selain kecepatan informasi yang bisa diakses dalam hitungan detik, menjadi diri sendiri dalam media sosial adalah alasan mengapa media sosial berkembang pesat. Tak terkecuali, keinginan untuk aktualisasi diri dan kebutuhan menciptakan personal branding[7], [8]. Media sosial adalah interaksi sosial antar manusia yang memproduksi berbagai dan bertukar informasi, hal ini mencakup gagasan dan berbagai konten dalam komunitas virtual[9]. Dalam hal ini, media sosial dapat dianggap sebagai peta jalan yang menjelajah unlimited market and society[10]. Menurut Kaplan dan Haenlein, media sosial adalah kelompok dari aplikasi berbasiskan internet yang dibangun atas dasar ideologi dan teknologi web versi 2.0 yang memungkinkan terciptanya website yang interaktif[11].

2. Harga

Harga adalah suatu nilai yang terkandung dalam suatu produk. Definisi harga sudah dikemukakan oleh beberapa ahli. Harga merupakan segala bentuk biaya moneter yang dikorbankan oleh konsumen untuk memperoleh, memiliki, memanfaatkan sejumlah kombinasi dari barang beserta pelayanan dari suatu produk[12]. Harga merupakan salah satu penentu keberhasilan suatu perusahaan karena harga menentukan seberapa besar keuntungan yang akan diperoleh perusahaan dari penjualan produknya baik berupa barang maupun jasa. Harga merupakan komponen yang berpengaruh langsung terhadap laba perusahaan[13], [14]. Tingkat harga yang ditetapkan mempengaruhi kuantitas yang terjual. Selain itu secara tidak langsung harga juga mempengaruhi biaya, karena kuantitas yang terjual berpengaruh pada biaya yang ditimbulkan dalam kaitannya dengan efisiensi produksi. Untuk pelanggan yang sensitif terhadap harga, harga yang murah biasanya adalah sumber kepuasan yang penting karena pelanggan akan mendapatkan value for money yang tinggi[15], [16]. Harga merupakan sejumlah nilai yang ditukarkan konsumen dengan manfaat dari mengkonsumsi atau menggunakan suatu barang atau jasa yang nilainya ditetapkan oleh pembeli dan penjual, melalui tawarmenawar atau ditetapkan oleh penjual untuk satu harga yang sama terhadap pembeli Harga memiliki perananan utama dalam proses pengambilan keputusan konsumen[17]. Fungsi harga yang pertama adalah membantu para pembeli untuk memutuskan cara memperoleh manfaat atau utilitas tertinggi yang diharapkan berdasarkan daya belinya. Yang kedua adalah peranan informasi harga. Fungsi harga dalam membidik kosnumen mengenai faktor-faktor produk, seperti kualitas. Hal ini terutama bermanfaat dalam situasi dimana pembeli memngalami kesulitan untuk menilai faktor produk atau manfaatnya secara objektif. Harga adalah sejumlah nilai yang dibebankan atas suatu produk atau jasa untuk jumlah dari nilai yang ditukar konsumen atas manfaat-manfaat[18]-[20].

3. Kualitas Produk

Adapun kualitas produk merupakan pemahaman bahwa produk yang ditawarkan oleh penjual mempunyai nilai jual lebih yang tidak dimiliki oleh produk pesaing. Sedangkan menurut Abbot, kualitas produk didefinisikan sebagai perbedaan dalam jumlah kualitas dan perbedaan kuantitas dalam bahan atau atribut yang diinginkan atau atribut [21]. Menurut Kotler, kualitas produk adalah kemampuan suatu produk untuk melakukan fungsi-fungsinya. Kemampuan tersebut meliputi, daya tahan, kehandalan, ketelitian yang dihasilkan, kemudahan pengoperasionalan, kemudahan dalam perbaikan, dan atribut yang berharga pada produk secara keseluruhan[22]. Kualitas produk adalah sebagai jumlah dari atribut atau sifat-sifat sebagaimana di deskripsikan dalam produk yang bersangkutan sehingga dengan demikian termasuk didalam kualitas ini adalah daya tahan dari produk, kenyamanan pemakai, daya guna dan lain. Kualitas produk adalah produk yang sesuai dengan yang disyaratkan atau distandarkan. Suatu produk memiliki kualitas apabila sesuai dengan standar kualitas yang telah ditentukan. Sedangkan menurut Juran, kualitas produk adalah kecocokan penggunaan produk untuk memenuhi kebutuhan dan kepuasan pelanggan[23]-[25].

4. Keputusan pembelian

Keputusan pembelian adalah suatu proses pemilihan salah satu dari beberapa alternatif penyelesaian masalah yang dikumpulkan oleh seorang konsumen, dan mewujudkannya dengan tindak lanjut yang nyata[23]. Keputusan pembelian adalah seleksi terhadap dua pilihan atau lebih. Dengan perkataan lain, pilihan alternatif harus tersedia bagi seseorang ketika pengambilan keputusan[26]. Setiap konsumen melakukan berbagai macam keputusan tentang pencarian, pembelian, penggunaan beragam produk 
dan merek pada setiap periode tertentu. Kotler dan Armstrong berpendapat bahwa keputusan pembelian konsumen adalah membeli merek yang paling disukai dari berbagai alternatif yang ada, tetapi dua faktor bisa berada antara niat pembelian dan keputusan pembelian. Faktor pertama adalah sikap orang lain dan faktor yang kedua adalah faktor situasional[27]. Oleh karena itu, preferensi dan niat pembelian tidak selalu menghasilkan pembelian yang actual. Menurut Boyd, dkk, keputusan pembelian konsumen merupakan suatu proses pemecahan masalah baik konsumen individu maupun pembeli organisasi melalui proses mental yang hampir sama dalam memutuskan produk dan merek apa yang akan dibeli. Jadi, semakin banyak pengetahuan pemasar tentang faktor-faktor yang mempengaruhi keputusan pembelian konsumen mereka, semakin besar kemampuan mereka untuk mendesain penawaran produk dan jasa yang menarik[28].

Beberapa penelitian mengemukakan bahwa variabel kualitas produk, harga dan promosi berpengaruh positif dan signifikan terhadap keputusan pembelian. Selain itu penelitian lainnya mengungkapan bahwa Analisis data menunjukkan harga berpengaruh positif terhadap keputusan pembelian, kualitas produk tidak berpengaruh terhadap keputusan pembelian, kualitas pelayanan berpengaruh positif terhadap keputusan pembelian serta harga dan kualitas pelayanan secara bersama-sama berpengaruh terhadap keputusan pembelian. Hasil penelitian lainnya menguatkan bahwa kualitas produk tidak berpengaruh terhadap keputusan pembelian pada Marketplace Shopee. Harga dan Promosi berpengaruh berpengaruh positif dan signifikan terhadap keputusan pembelian pada Marketplace Shopee[28]-[30].

Dalam penelitian lainnya, Hasil uji t menunjukkan kualitas produk dan harga secara parsial berpengaruh signifikan terhadap keputusan pembelian. Hasil uji $\mathrm{F}$ menunjukkan secara simultan kualitas produk dan harga berpengaruh signifikan terhadap keputusan pembelian[31], [32]. Hasil penelitian lainnya menunjukkan bahwa social media marketing dan kesadaran merek mempunyai pengaruh yang signifikan terhadap keputusan pembelian[33], [34].

Sehingga dapat dirumuskan hipotesis pertama:

H1: Ada pengaruh yang signifikan pemasaran menggunakan jejaring media sosial

Instagram terhadap keputusan pembelian di toko online Masker.Solopunya.
$\mathrm{H} 2$ : Ada pengaruh yang signifikan harga produk terhadap keputusan pembelian di toko online Masker.Solopunya.

H3: Ada pengaruh yang signifikan kualitas produk terhadap keputusan pembelian di toko online Masker.Solopunya.

H4: Ada pengaruh yang signifikan pemasaran menggunakan jejaring media sosial Instagram, harga dan kualitas produk terhadap keputusan pembelian di toko online Masker.Solopunya.

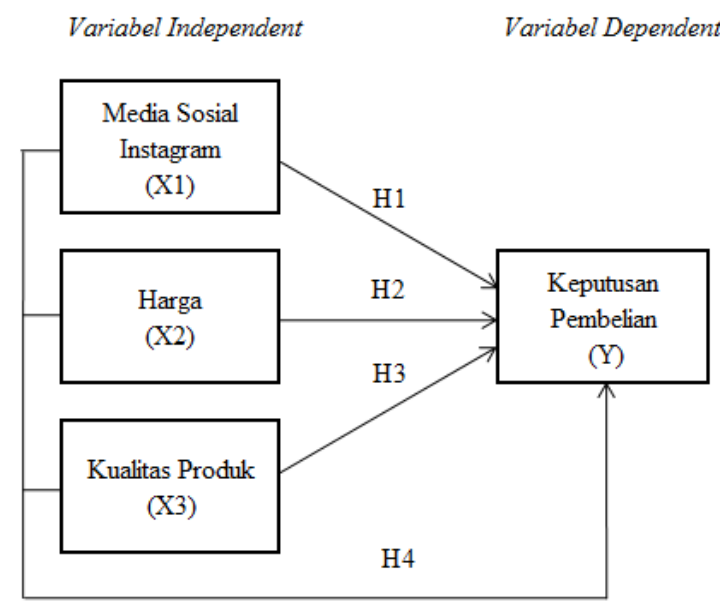

Gambar 1. Kerangka Berpikir

Berdasarkan kerangka berpikir di atas dapat diketahui bahwa variabel dalam penelitian ini dibedakan menjadi dua, yaitu variabel independent atau variabel bebas $(\mathrm{X})$ adalah Media Sosial Instagram (X1), Harga (X2) dan Kualitas Produk (X3) dan variabel dependent atau variabel terikat (Y) adalah keputusan pembelian (Y).

\section{METODE PENELITIAN}

Jenis penelitian yang digunakan dalam penelitian ini adalah penelitian kuantitatif. Penelitian ini menggunakan metode explanatory research atau penelitian eksplanatif. Data primer penelitian ini diperoleh secara langsung melalui hasil pengisian kuesioner oleh pengguna media sosial. Data sekunder yang digunakan dalam penelitian ini yang diperoleh berupa informasi dari situs internet, buku-buku, jurnal penelitian yang berkaitan dengan masalah penelitian. Metode pengambilan sampel yang digunakan dalam penelitian ini adalah dengan metode nonprobability sampling dengan teknik accidental sampling sehingga didapatkan sampel yang digunakan dalam penelitian ini sebanyak 85 orang. Dalam pengolahan data statistik peneliti menggunakan software SPSS version 17.0 for Windows. 


\section{HASIL DAN PEMBAHASAN}

Regresi Linier Berganda

Analisis ini digunakan untuk mengetahui ada tidaknya pengaruh media sosial Instagram, harga dan kualitas produk baik secara individual (parsial) atau bersamasama (simultan) terhadap keputusan pembelian. Hasil uji regresi linier berganda dapat disajikan dibawah ini

Tabel 1. Hasil Analisis Regresi Linier Berganda

\begin{tabular}{lcc}
\hline \multicolumn{1}{c}{ Model } & $\begin{array}{c}\text { Standardized } \\
\text { Coeficients }\end{array}$ & Sig \\
& $\frac{\mathrm{B}}{}$ & \\
\hline Media Sosial & 0,215 & 0,020 \\
Instagram(X1) & 0,224 & 0,024 \\
Harga (X2) & 0,407 & 0,000 \\
Kualitas Produk & & \\
(X3) & & \\
Sumber: Data diolah 2020. & &
\end{tabular}

Berdasarkan hasil perhitungan uji regresi linier berganda di atas, maka diperoleh persamaan regresi sebagai berikut:

$$
Y=0,215 X_{1}+0,224 X_{2}+0,407 X_{3}
$$

Koefisien hasil persamaan regresi di atas dapat diinterpretasikan sebagai berikut:

1. Koefisien beta variabel media sosial Instagram $\left({ }_{\beta} 1 \mathrm{X}_{1}\right)$ sebesar 0,215 menunjukan media sosial Instagram dapat berpengaruh terhadap keputusan pembelian (Y) secara positif. Apabila media sosial Instagram $\left(\mathrm{X}_{1}\right)$ ditingkatkan 1 poin maka peningkatan atas prediksi keputusan pembelian (Y) sebesar 0,215. Media sosial Instagram yang menarik akan membuat calon konsumen menjadi follower dan keterlibatan di Instagram tersebut membuat calon konsumen pada akhirnya memutuskan membeli.

2. Koefisien beta variabel harga $\left({ }_{\beta} 2 X_{2}\right)$ sebesar 0,224 menunjukan harga dapat berpengaruh terhadap keputusan pembelian (Y) secara positif. Apabila harga $\left(\mathrm{X}_{2}\right)$ ditingkatkan 1 poin maka peningkatan atas prediksi keputusan pembelian (Y) sebesar 0,224 . Oleh karena, harga yang kompetitif dibandingkan dengan toko online lain akan mempengaruhi calon konsumen untuk memilih membeli di toko ini.

3. Koefisien beta variabel kualitas produk $\left({ }_{\beta} 3 X_{3}\right)$ sebesar 0,407 menunjukan kualitas produk dapat berpengaruh terhadap keputusan pembelian (Y) secara positif. Apabila kualitas produk $\left(\mathrm{X}_{3}\right)$ ditingkatkan 1 poin maka peningkatan atas prediksi keputusan pembelian (Y) sebesar 0,407. Para calon konsumen sudah pandai menilai sisi kualitas, maka apabila kualitas masker diyakini benar-benar baik dan sesuai dengan yang dibutuhkan calon konsumen, maka tidak ragu memutuskan membeli.

Uji Hipotesis Parsial (Uji t)

Uji-t digunakan untuk menentukan seberapa besar pengaruh variabel independen secara parsial terhadap variabel dependen dengan membandingkan thitung dengan ttabel. Berdasarkan hasil perhitungan SPSS 17, hasil uji t didapatkan sebagai berikut:

Tabel 2. Hasil Uji t

\begin{tabular}{lccc}
\hline \multicolumn{1}{c}{ Variabel } & ttabel & thitung & Sig \\
& & & \\
\hline Media Sosial & 1,664 & 2,376 & 0,020 \\
Instagram(X1) & 1,664 & 2,299 & 0,024 \\
Harga (X2) & 1,664 & 4,240 & 0,000 \\
$\begin{array}{l}\text { Kualitas Produk } \\
\text { (X3) }\end{array}$ & & \\
Sumber: Data diolah 2020. & & \\
\end{tabular}

Berdasarkan tabel perhitungan di atas, maka dapat diinterpretasikan sebagai berikut:

1. Variabel media sosial Instagram berpengaruh positif dan signifikan secara parsial terhadap keputusan pembelian, hal ini terlihat dari thitung $2,376>$ ttabel 1,664 dan signifikan 0,020<0,05.

2. Variabel harga produk berpengaruh positif dan signifikan secara parsial terhadap keputusan pembelian, hal ini terlihat dari thitung 2,299> ttabel 1,664 dan signifikan 0,024<0,05.

3. Variabel kualitas produk berpengaruh positif dan signifikan secara parsial terhadap keputusan pembelian, hal ini terlihat dari thitung 4,240 > ttabel 1,664 dan signifikan $0,000<0,05$.

Uji Hipotesis Simultan (Uji F)

Uji $F$ digunakan untuk mengukur pengaruh variabel independen secara bersama-sama terhadap variabel dependen dengan membandingkan Fhitung dengan Ftabel. Nilai Fhitung akan diperoleh dengan menggunakan bantuan SPSS 17, kemudian akan dibandingkan dengan Ftabel pada tingkat $\alpha=5 \%$. Hasil uji F dapat disajikan sebagai berikut:

Tabel 3. Hasil Uji F

\begin{tabular}{cccc}
\hline Model & Ftabel & Fhitung & Sig \\
\hline Regresi & 2,72 & 20,975 & 0,000 \\
\hline \multicolumn{2}{c}{ Sumber: Data diolah 2020. }
\end{tabular}


Pada tabel di atas dapat dilihat bahwa Fhitung adalah 20,975 dengan tingkat signifikansi 0,000. Sedangkan Ftabel pada tingkat kepercayaan $95 \%(\alpha=0,05)$ adalah 2,72 . Oleh karena itu, Fhitung $(20,975)>$ Ftabel $(2,72)$ dan tingkat signifikansinya $0,000<0,05$ menunjukkan bahwa variabel independen (media sosial Instagram, harga dan kualitas produk) secara bersama-sama (simultan) berpengaruh positif dan signifikan terhadap keputusan pembelian masker di toko online "Masker.Solopunya".

\section{KESIMPULAN DAN SARAN}

Berdasarkan analisis yang telah didapatkan, maka penulis dapat menarik kesimpulan sebagai berikut: hasil uji $\mathrm{t}$ dapat disimpulkan bahwa media sosial Instagram, harga dan kualitas produk secara parsial berpengaruh signifikan terhadap keputusan pembelian di toko online "Masker.Solopunya". Berdasarkan hasil uji F dapat disimpulkan bahwa media sosial Instagram, harga dan kualitas produk secara simultan berpengaruh signifikan terhadap keputusan pembelian di toko online "Masker.Solopunya".

\section{REFERENSI}

[1] N. Alam Hamdani and G. Abdul Fatah Maulani, "The influence of E-WOM on purchase intentions in local culinary business sector," Int. J. Eng. Technol., vol. 7, no. 2.29, p. 246, 2018, doi: 10.14419/ijet.v7i2.29.13325.

[2] X. Lu, Y. Li, Z. Zhang, and B. Rai, "Consumer Learning Embedded in Electronic Word of Mouth," J. Electron. Commer. Res., vol. 15, no. 4, pp. 300-316, 2014.

[3] A. Bilgihan, "Gen y customer loyalty in online shopping: An integrated model of trust, user experience and branding," Comput. Human Behav., vol. 61, pp. 103-113, 2016, doi: 10.1016/j.chb.2016.03.014.

[4] L. Mileva and A. F. DH, "Pengaruh Social Media Marketing Terhadap Keputusan Pembelian," J. Adm. Bisnis, vol. 1, no. 1, pp. 190-199, 2018.

[5] N. A. Hamdani, A. Solihat, and G. A. F. Maulani, "The Influence of Information Technology and Co-Creation on Handicraft SME Business Performance," Int. J. Recent Technol. Eng., vol. 8, no. 1S, pp. 151-154, 2019, [Online]. Available: https://www.ijrte.org/download/volume-8issue- $1 \mathrm{~s} /$.
[6] S. Naurin Ahmad Assistant Professor of Marketing and M. Laroche Royal Bank Distinguished Professor, "Analyzing electronic word of mouth: A social commerce construct," Int. J. Inf. Manage., vol. 37, pp. 202-213, 2017, doi: 10.1016/j.ijinfomgt.2016.08.004.

[7] D. Belanche, I. Cenjor, and A. Pérez-Rueda, "Instagram Stories versus Facebook Wall: an advertising effectiveness analysis," Spanish J. Mark. - ESIC, vol. 23, no. 1, pp. 69-94, 2019, doi: 10.1108/SJME-09-2018-0042.

[8] K. Schwertner, "Digital transformation of business," Trakia J. Sci., vol. 15, no. Suppl.1, pp. 388-393, 2017, doi: 10.15547/tjs.2017.s.01.065.

[9] C. Efthymios, "Foundations of Social Media Marketing," Procedia - Soc. Behav. Sci., vol. 148, pp. 40-57, 2014, doi: 10.1016/j.sbspro.2014.07.016.

[10] Y. A. Aziz, Y. Y. Jusoh, S. Moghadas, R. Sohrabinezhadtalemi, H. Nezakati, and A. Amidi, "Review of Social Media Potential on Knowledge Sharing and Collaboration in Tourism Industry," Procedia - Soc. Behav. Sci., vol. 172, pp. 120-125, 2015, doi: 10.1016/j.sbspro.2015.01.344.

[11] A. M. Kaplan and M. Haenlein, "Users of the world, unite! The challenges and opportunities of Social Media," Bus. Horiz., vol. 53, no. 1, pp. 59-68, 2010, doi: 10.1016/j.bushor.2009.09.003.

[12] N. Sutrisno and A. D. Haryani, "Influence of Brand and Product Quality on Customer'S Buying Decision in South Cikarang Bekasi Regency," J. Lentera Bisnis, vol. 6, no. 1, p. 85, 2017, doi: 10.34127/jrlab.v6i1.169.

[13] S. Wahyuni and M. Ginting, "The Impact of Product Quality, Price and Distribution on Purchasing Decision on the Astra Motor Products in Jakarta," J. Bus. Manag. Account., vol. 1, no. 1, pp. 18-26, 2017.

[14] A. Rares and Rotinsulu Jopie Jorie, "THE EFFECT OF THE PRICE, PROMOTION, LOCATION, BRAND IMAGE AND QUALITY PRODUCTS TOWARDS THE PURCHASE DECISION OF CONSUMERS AT BENGKEL GAOEL STORE MANADO TOWN SQUARE," J. EMBA, vol. 3, no. 2, pp. 592-604, 2015.

[15] N. Prasastono and S. Y. F. Pradapa, "TERHADAP KEPUASAN KONSUMEN KENTUCKY FRIED CHICKEN," Din. 
Kepariwisataan, vol. 11, no. 2, pp. 13-23, 2012.

[16] P. Mega, B. Hypermall, and S. F. Wibowo, "PENGARUH IKLAN TELEVISI DAN HARGA TERHADAP KEPUTUSAN PEMBELIAN SABUN LUX ( SURVEI PADA," J. Ris. Manaj. Sains Indones., vol. 3, no. 1, pp. 1-15, 2012.

[17] H. Samhah, "PENGARUH KUALITAS LAYANAN DAN HARGA TERHADAP KEPUASAN KONSUMEN OOST KAFE SURABAYA," J. Ilmu dan Ris. Manaj. , vol. 5, no. 12, pp. 1-17, 2016.

[18] P. Kotler and L. L. Keller, Marketing Management, 14th ed. England: Pearson Education Limited, 2013.

[19] N. A. Hamdani, G. A. F. Maulani, and A. Solihat, "The Influence of Current Ratio, Debtto-equity ratio, inventory turnover, and return on investment on price-earnings ratio of cement industry companies listed at Indonesia Stock Exchange," in Advances in Business, Management and Entrepreneurship, Taylor \& Francis Group, LLC, 2020, pp. 498-504.

[20] A. Solihat, "Layanan Purna Jual pada Produk Otomotif," Bus. Innov. Entrep. J., vol. 1, no. 1, pp. 6-10, 2019, [Online]. Available: http://ejournals.fkwu.uniga.ac.id/index.php/BI EJ.

[21] M. L. Sheng and T. S. H. Teo, "International Journal of Information Management Product attributes and brand equity in the mobile domain: The mediating role of customer experience," Int. J. Inf. Manage., vol. 32, no. 2, pp. 139-146, 2012, doi: 10.1016/j.ijinfomgt.2011.11.017.

[22] K. L. Kotler, Philip dan Keller, Marketing Management, 14th ed. New Jersey: Pearson, 2012.

[23] A. ABDURRAHMAN and R. Anggriani, "Pengaruh Kualitas Produk, Kualitas Layanan, Harga, dan Lokasi terhadap Keputusan Pembelian," Bus. Innov. Entrep. J., vol. 2, no. 4, pp. 224-231, 2020, doi: 10.35899/biej.v2i4.174.

[24] M. Zulkarnain, "Kualitas Produk, Servicescape dan Word of Mouth Serta Pengaruhnya terhadap Keputusan Pembelian Ulang," Bus. Innov. Entrep. J., vol. 3, no. 1, pp. 38-44, 2021, doi: 10.35899/biej.v3i1.198.

[25] A. G. Ramadhan and S. B. Santosa, "Analisis
Pengaruh Kualitas Produk, Kualitas Pelayanan, dan Citra Merek terhadap Minat Beli Ulang pada sepatu Nike Running di Semarang melalui Kepuasan Pelanggan sebagai Variabel Intervening," Diponegoro J. Manag., vol. 6, no. 1, pp. 1-12, 2017, [Online]. Available: https://ejournal3.undip.ac.id/index.php/djom/a rticle/view/17525/16774.

[26] L. L. Schiffman, Leon G.; Kanuk, Consumer Behavior, 8th ed. Prentice Hall, 2004.

[27] P. Kotler and K. L. Keller, Marketing Management, vol. 22, no. 4. 2009.

[28] M. Poturak and M. Turkyilmaz, "The Impact of eWOM in Social Media on Consumer Purchase Decisions: A Comparative Study between Romanian and Bosnian Consumers," Manag. Econ. Rev., vol. 3, no. 2, pp. 138-160, 2018.

[29] L. K. I. DEVI, "PENGARUH KUALITAS PRODUK, HARGA DAN PROMOSI TERHADAP KEPUTUSAN PEMBELIAN PADA MARKETPLACE SHOPEE," UNIVERSITAS ISLAM NEGERI SUNAN AMPEL SURABAYA, 2019.

[30] I. Permana, "Customer Switching Behavior dalam Membeli Batik dari UKM," Bus. Innov. Entrep. J., vol. 1, no. 1, pp. 48-52, 2019, [Online].

Available: http://ejournals.fkwu.uniga.ac.id/index.php/BI EJ.

[31] F. MARGARETTA, "PENGARUH KUALITAS PRODUK DAN HARGA TERHADAP KEPUTUSAN PEMBELIAN HANDPHONE XIAOMI," SEKOLAH TINGGI ILMU EKONOMI PELITA BANGSA, 2017.

[32] M. Barreto and I. G. A. K. Giantari, "Kata Kunci :Strategi, Pengembangan, Objek Wisata, Air Panas, Marobo ABSTRACT," E-Jurnal Ekon. dan Bisnis Univ. Udayana, vol. 4, no. 11, pp. 773-796, 2015.

[33] M. Kurniasari and A. Budiatmo, "Pengaruh Social Media Marketing, Brand Awareness Terhadap Keputusan Pembelian Dengan Minat Beli Sebagai Variabel Intervening Pada J. Co Donuts \& Coffee Semarang," Diponegoro J. Soc. Polit., vol., no., pp. 1-8, 2018.

[34] A. Hamdani and G. A. Fatah, "Perencanaan Strategis Sistem Informasi pada Usaha Kecil dan Menengah," vol. 4, no. September, pp. 167-172, 2018. 